\title{
Sprawozdanie $z$ uroczystości nadania profesorowi Bogusławowi Śliwerskiemu tytułu doktora honoris causa przez Uniwersytet Kardynała Stefana Wyszyńskiego w Warszawie, 25 czerwca 2020 roku
}

Dnia 25 czerwca 2020 roku odbyła się w Uniwersytecie Kardynała Stefana Wyszyńskiego w Warszawie (UKSW) uroczystość nadania tytułu doktora honoris causa profesorowi Bogusławowi Śliwerskiemu. Z wnioskiem w tej sprawie do Senatu UKSW zwróciła się Rada Wydziału Nauk Pedagogicznych. Recenzentami dorobku profesora B. Śliwerskiego byli prof. dr hab. Agnieszka Cybal-Michalska i prof. dr hab. Józef Górniewicz. Uchwałę o nadaniu tytułu podjął Senat UKSW w dniu 27 lutego 2020 roku. W uzasadnieniu wskazano, że: „Profesor Bogusław Śliwerski należy do elitarnego grona współczesnych uczonych o międzynarodowej renomie. Jest wybitną osobowością, która poprzez swoją szeroką działalność oddziałuje na aktywność naukowo-badawczą, dydaktyczną i organizacyjną polskiego środowiska pedagogicznego oraz na tożsamość polskiej myśli pedagogicznej. Nieustannie wprowadza zaczyn do nowych badań i dyskusji poprzez oryginalne spojrzenie na pedagogikę, wszechstronność i interdyscyplinarność naukową. Posiada imponujący dorobek publikacyjny. Prowadzi działalność ekspercką i doradczą w różnych gremiach krajowych i zagranicznych. Senat UKSW zwraca również uwagę na wybitne osiągnięcia Laureata w budowaniu mostów solidarności między różnymi środowiskami naukowymi" (Uchwała nr 25/2020).

Do tej pory profesor B. Śliwerski otrzymał tytuł doktora honoris causa od trzech polskich uniwersytetów: Uniwersytetu Marii Curie Skłodowskiej w Lublinie (2014), Uniwersytetu Kazimierza Wielkiego w Bydgoszczy (2016) i Katolickiego

* Dr hab. Dariusz Stępkowski, prof. ucz., Uniwersytet Kardynała Stefana Wyszyńskiego w Warszawie, Wydział Nauk Pedagogicznych; e-mail: d.stepkowski@uksw.edu.pl. 
Uniwersytetu Lubelskiego Jana Pawła II w Lublinie (2017), i zagranicznej jednostki naukowej - Narodowej Akademii Nauk Pedagogicznych Ukrainy (2019). Ponadto jest on profesorem honorowym Uniwersytetu Warmińsko-Mazurskiego w Olsztynie i Uniwersytetu Śląskiego.

Uroczystość nadania tytułu i wręczenia dyplomu doktora honoris causa odbyła się w auli Jana Pawła II, w której zgromadzili się zaproszeni goście i przedstawiciele środowiska naukowego. Z uwagi na pandemię w uroczystości mogła wziąć udział ograniczona liczba osób. Jej przebieg był transmitowany na żywo w internecie.

Uroczyste zebranie rozpoczęło się od odśpiewania hymnu państwowego. Następnie głos zabrał rektor UKSW, ks. prof. dr. hab. Stanisław Dziekoński, który powitał laureata i zgromadzone osoby, a w szczególności Agnieszkę Śliwerską, małżonkę profesora B. Śliwerskiego; rektora Akademii Pedagogiki Specjalnej im. M. Grzegorzewskiej, prof. dr. hab. Stefana Kwiatkowskiego; rektora Chrześcijańskiej Akademii Teologicznej w Warszawie, prof. ucz., dr. hab. Bogusława Milerskiego; dziekana Wydziału Nauk o Wychowaniu Uniwersytetu Łódzkiego, prof. dr hab. Danutę Urbaniak-Zając; przewodniczącą Polskiego Towarzystwa Pedagogicznego, prof. dr hab. Joannę Madalińską-Michalak oraz oboje recenzentów - prof. dr hab. Agnieszkę Cybal-Michalską i prof. dr. hab. Józefa Górniewicza. Rektor UKSW podziękował profesorowi B. Śliwerskiemu za przyjęcie tytułu i podkreślił, że jest to wyraz wdzięczności nie tylko Wydziału Nauk Pedagogicznych UKSW, lecz także całego środowiska akademickiego uczelni za jego wkład w budowanie mostów porozumienia i wzajemnego szacunku.

Później prof. ucz., ks. dr. hab. Zbigniew Babicki, prodziekan Wydziału Nauk Pedagogicznych UKSW, odczytał wspomnianą powyżej uchwałę Senatu UKSW. Po czym prorektor UKSW ds. studenckich i kształcenia, prof. ucz., dr hab. Anna Fidelus, odczytała laudację, którą przygotował promotor - prof. dr hab. Jarosław T. Michalski, nieobecny na uroczystości. W laudacji naszkicowany został życiorys naukowy laureata i jego wkład w rozwój nauk o wychowaniu w Polsce. W dalszej części uroczystości głos zabrał prof. ucz., ks. dr hab. Z. Babicki, prodziekan Wydziału Nauk Pedagogicznych UKSW, który oczytał sporządzony w języku łacińskim tekst na dyplomie doktoratu honoris causa. Aktu uroczystego wygłoszenia formuły nadania tytułu i wręczenia dyplomu dokonał rektor UKSW, ks. prof. dr hab. S. Dziekoński. Zgodnie z ceremoniałem został odśpiewany hymn Gaude Mater Poloniae. Później prorektor UKSW ds. nauki i współpracy międzynarodowej i równocześnie rektor elekt, ks. prof. dr hab. Ryszard Czekalski, odczytał list gratulacyjny nadesłany przez Radę Doskonałości Naukowej i Centralnej Komisji ds. Stopni i Tytułów.

Po tym głos zabrał dostojny doktor honoris causa, który wygłosił wykład zatytułowany Prymas Tysiąclecia kardynał Stefan Wyszyński - pedagogia odwagi i pozytywnego oporu wobec przemocy. Na wstępie nawiązał do swoich osobistych związków z UKSW, uczelnią, która zaszczyciła go najwyższą godnością, jaką współcześnie uczony może otrzymać za swoją działalność. W nawiązaniu do postaci 
i nauczania kardynała Stefana Wyszyńskiego profesor B. Śliwerski zwrócił uwagę na wypowiedzi Prymasa pozostające do dziś wezwaniem do odwagi i pozytywnego oporu wobec przejawów dyskryminacji chrześcijaństwa w społeczeństwie polskim. W odniesieniu do szkoły, która wciąż pozostaje przedmiotem sporu ideologicznego, mówca przytoczył następujące słowa Prymasa Tysiąclecia: „Szkoła jest narodowa i należy do narodu, do rodziny i społeczeństwa, a nie do takiej czy innej partii, sekty czy ugrupowania zajmującego się niechwalebnym, a nawet wrogim i szkodliwym dla Narodu i państwa dziełem - wyrywania wiary z serc dzieci i młodzieży. [...] nie ma takiej władzy a ziemi, która mogłaby bez pogwałcenia wolności odmówić rodzicom prawa do wychowania dzieci w duchu religijnym".

$\mathrm{Na}$ zakończenie doktor honoris causa podziękował organom i władzom uniwersytetu, w tym jego rektorowi, dziekanowi Wydziału Nauk Pedagogicznych i całej społeczności akademickiej za obdarzenie go zaszczytnym tytułem. Słowa wdzięczności skierował również do swojej małżonki, a także mamy, która uczestniczyła w uroczystości on-line, rodzeństwa i współpracowników przybyłych z Uniwersytetu Łódzkiego. Kończąc, stwierdził, że swoją pracę traktuje jako służbę Bogu i Ojczyźnie, w tym nauce i oświacie.

Po wykładzie ponownie głos zabrał rektor UKSW, ks. prof. dr. hab. Stanisław Dziekoński, który podziękował za przypomnienie dziedzictwa Prymasa Tysiąclecia w tym szczególnym dla UKSW roku jubileuszu 2o-lecia istnienia i beatyfikacji kard. Stefana Wyszyńskiego. Uroczystość zamknęło odśpiewanie studenckiej pieśni Gaudeamus igitur. 